Vol 3 No 3 (2022) 584-598 P-ISSN 2620-295 E-ISSN 2747-0490 DOI: 1047467/elmal.v3i3.941

\title{
Studi Literature Strategi BMT Dalam Pemberdayaan Ekonomi Ummat Berbasis Masjid
}

\author{
1 Pandapotan, ${ }^{2}$ Andri Soemitra \\ 1,2 Universitas Islam Negeri Sumatera Utara, Medan \\ dapot64@gmail.com
}

\begin{abstract}
This study aims to examine how the strategies used by BMT in empowering and improving the economy of mosque-based congregations. Mosques are not only used for worship activities but can also empower the congregation's economy. A mosque with all the potential that exists can establish Baitul Maal wal Tamwil for its independence. This study uses selected literature. The research method used is a literature study by collecting articles related to the research theme downloaded from Google Scholar for publication in the last 5 years. Then a content analysis was carried out in accordance with the Researcher's Discussion Topic, namely the BMT Strategy in Empowering a Mosque-Based Economy so that 41 articles were obtained. The main finding of this research from a literature review shows that the establishment of a mosque-based BMT can significantly improve the economy of the congregation. The BMT strategies used are: ZISWAF for Economic Empowerment, Human Resources, Transparency and Accountability, Finance Inclusion, Marketing Management, Implementation of Sharia Economic Contracts, BMT Performance, Establishment of BMT, Integration of ZISWAF with BMT, and Role Models.
\end{abstract}

Keywords: BMT, Empowerment, Mosque.

\begin{abstract}
Abstrak
Studi ini bertujuan untuk meneliti bagaimana strategi yang dilakukan BMT dalam memberdayakan dan meningkatkan ekonomi jamaah berbasis masjid. Masjid tidak hanya digunakan sebatas kegiatan ibadah saja tetapi dapat juga memberdayakan ekonomi jamaah. Masjid dengan segala potensi yang ada dapat mendirikan Baitul Maal wal Tamwil untuk kemandiriannya. Penelitian ini menggunakan berdasarkan literatur terpilih. Adapun metode penelitian yang dilakukan menggunakan studi literature dengan mengumpulkan artikel yang terkait dengan tema peneliti yang diunduh dari Google Scholar untuk penerbitan 5 tahun terakhir. Kemudian dilakukan analisis konten yang sesuai dengan Topik Pembahasan Peneliti yaitu Strategi BMT Dalam Memberdayakan Ekonomi Berbasis Masjid sehingga diperoleh 41 artikel. Temuan utama penelitian ini dari kajian studi literatur menunjukan bahwa pendirian BMT berbasis masjid signifikan dapat meningkatkan ekonomi jamaah. Adapun strategi BMT yang digunakan adalah : ZISWAF Untuk Pemberdayaan Ekonomi, Sumber Daya Manusia, Transfaransi dan Akuntanbilitas, Finance Inclusi, Manajemen Marketing, Penerapan Akad Syariah Ekonomi, Kinerja BMT, Pendirian BMT, Integrasi ZISWAF dengan BMT, dan Tokoh Panutan.
\end{abstract}

Kata Kunci : BMT, Pemberdayaan, Masjid.

\section{PENDAHULUAN}

Praktik keuangan syariah di Indonesia dimulai pada tahun 1993 dengan berdirinya Bank Muamalat Indonesia. Ketika keuangan Islam mulai dikenal, keuangan mikro syariah juga mulai berkembang di tahun 1990-an melalui lembaga formal seperti koperasi syariah, koperasi berbasis pesantren dan Baitul Mal Wa Tamwil (BMT). BMT memiliki banyak fitur unik dibandingkan dengan penyedia keuangan mikro lainnya di Indonesia (Wulandari \& Kassim, 


\section{Vol 3 No 3 (2022) 584-598 P-ISSN 2620-295 E-ISSN 2747-0490 DOI: 1047467/elmal.v3i3.941}

2016). Dia menggunakan pendekatan berbasis keluarga yang cocok diterapkan di kalangan masyarakat miskin dan berlisensi dan diawasi oleh Kementerian Koperasi dan Usaha Kecil Menengah. Beberapa BMT terintegrasi dengan kelompok pengusaha mikro, namun BMT belum menunjukkan hasil dalam pemberdayaan berbasis masjid.

BMT memiliki keunikan yaitu dapat menawarkan fungsi ganda sebagai Baitul Maal (rumah harta), di mana ia memainkan peran menghimpun dan menyalurkan dana dari zakat, infaq dan sedekah, dan sebagai Baitul Tamwil yang intinya menawarkan intermediasi keuangan dengan mengelola pendanaan dan menabung. Fungsi-fungsi ini menyiratkan bahwa BMT adalah entitas sosial dan sekaligus sebagai badan Usaha. Sebagai Baitul Tamwil, BMT berperan peran sebagai koperasi dengan mekanisme bagi hasil dengan nilai tambah Islami dan aktivitas kelompok sebagai teknik mitigasi risikonya. Sedangkan apabila dilihat dari status badan hukumnya, BMT merupakan organisasi lembaga keuangan mikro dalam bentuk Kelompok Simpan Pinjam (KSP) atau Kelompok Swadaya Masyarakat (KSM).

Dalam konteks Indonesia, penduduk miskin didominasi oleh Muslim yang bekerja disektor informal. Oleh karena itu, keuangan mikro syariah melalui Baitul Mal wat Tamwil memiliki peluang besar untuk berkontribusi dalam mengurangi kemiskinan. Hal ini karena, pada dasarnya, BMT berfokus pada perkembangan umat Islam di Indonesia. Masjid sebagai lembaga keagamaan merupakan tempat perjumpaan dan berkumpulnya umat secara rutin dengan hati dan pikiran yang lebih jernih ketimbang mereka bertemu di tempat-tempat lain. Ketika mereka berada di masjid maka akan lebih terbuka dan lebih jernih pikiran dan hatinya, karena di masjid umat akan lebih dekat kepada Allah SWT. Pada satu sisi masjid adalah tempat untuk bermunajat kepada Allah SWT, dan pada sisi lain merupakan ruang publik untuk bersamasama membahas berbagai persoalan keumatan yang ada di lingkungannya. Oleh karena itu, jamaah masjid adalah basis-basis komunitas yang sangat kokoh (Alwi, M.A., 2020).

Hasil penelitian (Muhammad Akhyar Adnan Shochrul, 2015) mengungkapkan bahwa pembiayaan BMT efektif dalam mengurangi kemiskinan. Kebanyakan Nasabahnya dapat meningkatkan pendapatannya setelah menerima pembiayaan BMT. Produk BMT, khususnya dengan akad mudharabah untuk memberdayakan masyarakat miskin di berbagai usaha produktif telah mampu mengurangi tingkat dan keparahan kemiskinan. Cara kerja BMT, sehingga dapat lebih berkontribusi dalam pengayaan pengetahuan, serta perkembangan BMT secara umum dalam mewujudkan misinya

Data OJK menunjukkan jumlah Lembaga Mikro berbasis syariah sebesar 36\% atau sebanyak 62 unit dari 174 unit Lembaga Mikro yang terdaftar di OJK, ini menunjukkan bahwa ummat islam yang mayoritas $80 \%$ di Indonesia belum menunjukkan kontribusinya dalam bidang ekonomi.

Tabel 1: Data Lembaga Keuangan Mikro OJK di Indonesia 


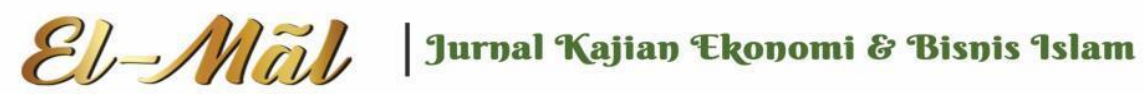

Vol 3 No 3 (2022) 584-598 P-ISSN 2620-295 E-ISSN 2747-0490 DOI: 1047467/elmal.v3i3.941

\begin{tabular}{|c|c|c|c|c|c|}
\hline \multirow{2}{*}{ NO } & \multirow{2}{*}{ PROPIINSI } & \multicolumn{3}{|c|}{ LEMBAGA KEUANGAN MIKRO OJK } & \multirow{2}{*}{$\begin{array}{c}\text { PERSENTASE } \\
\text { SYARIAH }\end{array}$} \\
\hline & & KONVENSIONAL & SYARIAH & TOTAL & \\
\hline 1 & Aceh & & 1 & 1 & $100 \%$ \\
\hline 2 & Banten & 4 & 3 & 7 & $43 \%$ \\
\hline 4 & DIY & 2 & 3 & 5 & $60 \%$ \\
\hline 5 & Jambi & & 1 & 1 & $100 \%$ \\
\hline 6 & Jawa Barat & 10 & 12 & 22 & $55 \%$ \\
\hline 8 & Jawa Timur & 1 & 15 & 16 & $94 \%$ \\
\hline 9 & Kalimantan Tengah & 1 & & 1 & $0 \%$ \\
\hline 10 & Kalimantan Timur & & 1 & 1 & $100 \%$ \\
\hline 11 & Lampung & 6 & 2 & 8 & $25 \%$ \\
\hline 12 & NTB & 2 & & 2 & $0 \%$ \\
\hline 13 & Papua & & 1 & 1 & $100 \%$ \\
\hline 17 & Sulawesi Selatan & & 1 & 1 & $100 \%$ \\
\hline 18 & Sumatera Barat & 6 & 2 & 8 & $25 \%$ \\
\hline \multirow[t]{3}{*}{19} & Sumatera Utara & 1 & 2 & 3 & $67 \%$ \\
\hline & JUMLAH & 112 & 62 & 174 & $36 \%$ \\
\hline & PROSENTASE & $64 \%$ & $36 \%$ & $100 \%$ & \\
\hline
\end{tabular}

Sumber: LKM OJK

Fakta lapangan sementara juga menunjukkan bahwa rata-rata pengurus masjid belum mendapatkan dorongan dan bimbingan, khususnya mengenai bagaimana teknik/cara mengelola bisnis melalui masjid. Untuk itu perlu dilakukan penelitian lebih jauh dan lebih dalam mengenai prospek pemberdayaan ekonomi Islam berbasis masjid. Bertitik tolak dari latar belakang tersebut, maka permasalahan pokok yang akan dikaji dalam penelitian ini adalah; "Bagaimana prospek pemberdayaan ekonomi masyarakat melalui masjid dijabarkan ke dalam tiga sub masalah sebagai berikut: (1). Bagaimana strategi pemberdayaan ekonomi ummat melalui masjid ? (2). Bagaimana peran BMT dalam meningkatkan ekonomi ummat melalui masjid? (3). Bagaimana mendorong pertumbuhan usaha ekonomi masyarakat berbasis masjid?

\section{METODE PENELITIAN}

Penelitian ini dilakukan dengan menganalisis artikel terpilih yang membahas Strategi BMT Memberdayakan Ekonomi Ummat Berbasis Masjid terhadap upaya meningkatkan kegiatan ekonomi untuk kemandirian ummat terbebas dari kemiskinan. Penelitian ini terdiri dari beberapa tahapan. Pertama, untuk mengumpulkan data dilakukan pencarian dengan menggunakan kata kunci "BMT", dan "Masjid dengan menggunakan basis data Google Scholar. Kedua, dilakukan analisis terhadap data artikel dengan menyesuaikan dengan tema penelitian yaitu pemberdayaan ekonomi ummat berbasis masjid dengan pendirian BMT sehingga diperoleh 41 artikel. Tahap ketiga mengelompokan artikel terkait penulis, fokus strategi BMT dalam menggerakan ekonomi. Hasil analisis diharapkan memperkuat hasil penelitian terdahulu terhadap fakta dampak keberadaan BMT di masjid dapat meningkatkan kegiatan ekonomi untuk menurunkan angka kemiskinan ummat khususnya jamaah masjid.

\section{HASIL DAN PEMBAHASAN}

\section{BMT dan Fungsi Masjid}

Di Indonesia, Koperasi Keuangan Syariah yang dikenal dengan Baitul Maal wat Tamwil (BMT) telah berpengaruh dalam meningkatkan status sosial ekonomi peserta dengan menyediakan keuangan skala kecil pelayanan dan program pembangunan sosial kepada rumah tangga miskin dan berpenghasilan rendah. Selain itu, hasil penelitian (Quraisy et al., 2017) 


\section{Vol 3 No 3 (2022) 584-598 P-ISSN 2620-295 E-ISSN 2747-0490 DOI: 1047467/elmal.v3i3.941}

menunjukkan bahwa Lembaga Keuangan Mikro Syariah (LKM) khususnya BMT telah berkontribusi dalam meningkatkan kesejahteraan peserta dan kualitas hidup.

Baitul Maal Wat Tamwil sebagai varian dari LKM syariah di Indonesia dan telah ditetapkan sebagai LKM berbasis masyarakat yang beroperasi di bawah sistem koperasi dan domain organisasi non-pemerintah. Selain itu, BMT merupakan organisasi ekonomi yang fokus pada pengembangan kerjasama dan investasi untuk mengembangkan usaha mikro dan mengentaskan kemiskinan melalui sistem bagi hasil (Maulana \& Akbar, 2019).

Islam menawarkan solusi unik untuk masalah kemiskinan melalui pemanfaatan beberapa mekanisme untuk memerangi kemiskinan seperti zakat, wakaf dan pinjaman tanpa bunga (qardhul hasan). Selain itu, masalah kemiskinan di mayoritas Muslim dapat diatasi dengan mengintegrasikan tanggung jawab sosial perusahaan dengan sektor Islam, yaitu sistem wakaf dan zakat sebagai alat intervensi berbasis agama untuk pengurangan kemiskinan di negara-negara mayoritas Muslim. Tantangan BMT adalah menyempurnakan konsep keuangan mikro syariah dalam menawarkan pembiayaan syariah yang efektif dan mampu menawarkan peningkatan status sosial ekonomi masyarakat miskin Muslim di Indonesia (Wulandari, 2019).

Masjid pada era Rasulullah sebagai pusat aktivitas umat. Dimana masjid pada saat itu berfungsi sebagai sumber peradaban, tempat menyusun strategi perang, politik, pendidikan, bisnis, seni, termasuk masalah-masalah sosial dibicarakan dan dicarikan solusinya dari dalam masjid. Masjid memiliki dua misi. Misi pertama, sebagai wahana pembersihan diri, dimana masjid sebagai pusat ibadah memfasilitasi setiap muslim untuk selalu menjalankan perintah Allah dan menjauhi larangan-Nya. Misi kedua, adalah pembebasan dan pemberdayan, dimana masjid bertugas untuk mewujudkan manusia yag tidak diperbudak oleh sesamanya dan oleh makhluk-makhluk lainnya. Masjid sebagai pusat aktivitas yang demikian, tidak lagi dijumpai pada zaman sekarang. Bahkan masjid kini difahami sebagai tempat ibadah.

Setelah hijrah ke Madinah kegiatan pertama dari gerakan Nabi adalah mendirikan masjid. Nabi bersama sabat bergotong royong membangun masjid, selain berfungsi sebagai tempat ibadah, masjid juga difungsikan untuk beberapa tujuan lain, seperti: tempat pertemuan parlemen (Dewan Perwakilan Rakyat), kesekertariatan mahkamah agung, markas besar tentara, kantor urusan luar negeri, rumah bagi para tamu, pusat pendidikan, tempat pelatihan bagi para penyebar luas agama (seperti pesantren), asrama, baitul maal, tempat para dewan, dan utusan. Singkatnya, pada waktu itu masjid sebagai Islamic Centre.

BMT yang menjadi lembaga keuangan umat sudah ada pada masa Rasulullah saw (1-11 H/622-632 M). Ketika kaum muslimin mendapatkan ghanimah (harta rampasan perang) pada Perang Badar. Saat itu para shahabat berselisih paham mengenai cara pembagian ghanimah tersebut sehingga turun firman Allah swt dalam Al-Qur'an surat Al-Anfal ayat 1 yang artinya: Mereka bertanya kepadamu (Muhammad) tentang (pembagian) harta rampasan perang. Katakanlah, Harta rampasan perang itu adalah milik Allah dan Rasul, oleh sebab itu bertaqwalah kepada Allah dan perbaikilah hubungan di antara sesama kalian, dan taatlah kepada Allah dan Rasul-Nya jika kalian benar-benar orang-orang yang beriman.' (QS. al Anfal (8):1)

Sementara itu di Indonesia, yang mayoritas penduduknya beragama Islam, ada kerinduan terhadap munculnya kembali lembaga keuangan pada awal Islam. Hal ini di samping semangat keberagamaan yang semakin meningkat, juga didorong dengan gagalnya lembagalembaga ekonomi yang ada dalam meningkatkan produktifitas dan kegiatan ekonomi yang ada pada era pasar bebas. Akhirnya, pada akhir Oktober 1995 di seluruh Indonesia telah berdiri lebih dari 300 Baitul Mal Wa Tamwil, 10 yang dalam istilah Indonesia dinamakan dengan Balai Usaha Mandiri Terpadu (disingkat BMT), dan masing-masing BMT melayani 100-150 pengusaha kecil bawah (Fadhilah \& Zaki, 2019). 


\section{Vol 3 No 3 (2022) 584-598 P-ISSN 2620-295 E-ISSN 2747-0490 DOI: 1047467/elmal.v3i3.941}

Secara konsepsi BMT adalah suatu lembaga keuangan yang di dalamnya mencakup dua jenis kegiatan sekaligus, yaitu: Kegiatan mengumpulkan dana dari berbagai sumber seperti zakat, infaq dan sedekah, dan lain-lain yang dapat dibagikan/disalurkan kepada yang berhak dalam mengatasi kemiskinan. Selanjutnya kegiatan produktif dalam rangka menciptakan nilai tambah baru dan mendorong pertumbuhan ekonomi yang bersumber dari manusia. BMT direkayasa menjadi lembaga solidaritas sekaligus lembaga ekonomi rakyat kecil untuk bersaing di pasar bebas. BMT berupaya menjadi jawaban terhadap problematika keuangan dan kemiskinan. Isu kesejahteraan dan pemberdayaan ekonomi umat adalah hal yang menjadi tujuan dimunculkannya BMT pada era modern ini. Hasil penelitian menunjukkan bahwa ada tiga bangunan utama yang sedang berkembang model bisnis Islami yang terdiri dari fondasi bisnis, desain bisnis, dan pengembangan bisnis (Hendratmi \& Widayanti, 2017).

\section{Strategi Pemberdayaan Ekonomi Ummat berbasis Masjid}

\section{Pemberdayaan}

Pemberdayaan ekonomi masyarakat adalah penguatan pemilikan faktor-faktor produksi, penguatan penguasaan distribusi dan pemasaran, penguatan masyarakat untuk mendapatkan gaji/upah yang memadai, dan penguatan masyarakat untuk memperoleh informasi, pengetahuan dan ketrampilan, yang harus dilakukan secara multi aspek, baik dari aspek masyarakatnya sendiri, mapun aspek kebijakannya (Muthalib, 2018). BMT dapat menjadikan pemberdayaan sebagai sebuah stritegi utama yang dapat dilakukan untuk meningkatkan minat dan kekuatan masyarakat miskin untuk mengembangkan dirinya.

\section{Sistem Informasi Akuntansi}

Sebuah perusahaan membutuhkan bahasa yang dapat mengkomunikasikan informasi ekonomi. Akuntansi merupakan suatu media informasi, dimana dapat dikatakan bahwa akuntansi sebagai bahasa bisnis. Sehingga akuntansi merupakan proses pengumpulan, pengklasifikasian, pencatatan, pelaporan, analisis dan interpretasi data keuangan untuk memenuhi kebutuhan informasi dari berbagai pihak yang bersangkutan dengan operasi bisnis baik secara internal (dalam bisnis). ) dan eksternal (di luar bisnis)". Sistem informasi akuntansi dapat dibedakan berdasarkan prosesnya, yaitu manual dan terkomputerisasi. Sistem informasi akuntansi adalah suatu sistem yang mengolah data dan transaksi untuk menghasilkan informasi yang berguna untuk perencanaan, pengendalian dan pengoperasian bisnis. Informasi akuntansi diperlukan oleh perusahaan untuk mengevaluasi kinerjanya (Zatalini \& Subaweh, 2019).

Perusahaan membutuhkan sistem informasi akuntansi terkomputerisasi yang efektif dan efisien. Oleh karena itu, diperlukan suatu pengembangan sistem dari manual menjadi terkomputerisasi. Pengertian pengembangan sistem adalah proses memodifikasi atau mengganti sebagian atau seluruh sistem informasi. Dalam mengembangkan sistem biasanya terdiri dari tiga langkah yaitu perencanaan dan analisis sistem, perancangan sistem dan implementasi sistem.

Sedangkan perencanaan sistem adalah proses mengidentifikasi subsistem yang ada pada sistem informasi yang pengembangannya memerlukan perhatian khusus dan analisis sistem adalah proses untuk mengidentifikasi subsistem yang akan dikembangkan. Desain sistem adalah proses penentuan dan data yang dibutuhkan oleh sistem baru. Implementasi sistem adalah proses penerapan prosedur dan metode yang telah dirancang ke dalam operasi.

\section{Inklusi dan Literasi Finansial}




\section{Vol 3 No 3 (2022) 584-598 P-ISSN 2620-295 E-ISSN 2747-0490 DOI: 1047467/elmal.v3i3.941}

Literasi keuangan syariah diperlukan untuk menjaga masyarakat dari transaksi riba. Semua orang yang mengerti tentang transaksi keuangan syariah akan tetap terjaga di sisi maqashid syariah terjaga dari segi agama dan kekayaan. Di Indonesia, literasi keuangan syariah masih perlu didorong oleh banyak pihak yang telah kompetensi yang tepat. Pelaksanaan edukasi agar masyarakat memahami literasi keuangan syariah adalah tanggung jawab para pengelola lembaga keuangan syariah. Oleh karena itu, BMT sebagai salah satu bentuk lembaga keuangan Islam juga wajib melakukan literasi keuangan syariah kepada anggotanya. Terutama agar sebagian besar anggota BMT semakin memahami pentingnya bertransaksi halal (Wibowo, 2020).

Dalam menerapkan literasi keuangan syariah, BMT memanfaatkan sisi Baitul Maalnya. Karena Baitul Maal memiliki peran sosial dan dapat melakukan proses pendidikan secara langsung kepada masyarakat yang teridentifikasi miskin. Baitul Maal tampil dapat menjadi pendidikan literasi keuangan syariah dengan membentuk kelompok belajar dalam keluarga dengan tujuan agar literasi keuangan syariah efektif menjadi unit terkecil dalam keluarga.

Inklusi finansial yang masih rendah di Indonesia terjadi disebabkan oleh dua kemungkinan kondisi masyarakat yaitu : Pertama, tidak punya akses karena tidak mau atau tidak mampu, dan kedua, punya akses. Bagi kelompok yg tidak mau dapat disebabkan karena alasan merasa tidak perlu atau karena alasan agama, budaya, dan sebagainya.Sedangkan bagi yang tidak dapat disebabkan karena tidak cukup pendapatan, risiko terlalu tinggi atau karena persyaratan tidak memenuhi.

Berdasarkan hal di atas, perlu diidentifikasi bagaimana peran BMT dalam memecahkan persoalan tersebut. Searah dengan program pemerintah dalam rangka meningkatkan kesejahteraan ekonomi melalui pengentasan kemiskinan, ada beberapa strategi yang ditempuh, yaitu : Sosial inclusion (akses terhadap fasilitas dasar), financial inclusion (akses terhadap jasa keuangan) dan economic inclusion berupa peluang mengakses kegiatan usaha produktif bagi kaum miskin.

Financial Inclusion atau Inklusi keuangan adalah kegiatan menyeluruh yang bertujuan meniadakan segala bentuk hambatan baik yang bersifat harga maupun non harga terhadap akses masyarakat dalam memanfaatkan layanan jasa keuangan (Khatimah, 2016). Keberadaan BMT untuk pemberdayaan potensi ekonomi ummat mempunyai keunggulannya yaitu:

BMT menggunakan prinsip syariah dimana pola yang diterapkan adalah berbagi resiko sehingga cenderung mengajak mitranya terlibat bekerjasama, bukan sekedar hubungan antara lembaga keuangan dan nasabah dalam konteks mengucurkan bantuan dana dan kemudian memungut setoran semata seperti yang diterapkan bank konvensional atau lembaga keuangan mikro konvensional. Maka dengan pola berbagi resiko ini kesuksesan mitra adalah kesusksesan BMT sebaliknya kemunduran mitra dalam pengelolaan usahanya adalah juga kemunduran BMT.

> Pola berbagi resiko yang mengarahkan hubungan kerjasama dan kemitraan BMT dengan mitranya diatas, maka BMT sekaligus adalah wadah yang potensial bagi pembangunan bibit entrepreneurship baru dikalangan orang muda usia produktif yang masih menganggur di Indonesia.

$>$ Lembaga keuangan syariah lainnya yang berbentuk Bank yang cenderung sulit untuk menjangkau lapisan masyarakat paling bawah, BMT adalah lembaga yang potensial untuk menjangkau lapisan paling bawah dikarenakan dengan landasan Islam yang dimilikinya maka secara ideologis misinya adalah berupaya untuk mengangkat derajat kaum mustad'afin. Konsep ini sejalan dengan konsep Financial Inclusion yang bertujuan 


\section{Vol 3 No 3 (2022) 584-598 P-ISSN 2620-295 E-ISSN 2747-0490 DOI: 1047467/elmal.v3i3.941}

untuk meningkatkan akses pelayanan jasa keuangan terutama untuk masyarakat kecil dan menengah.

\section{Strategi Pemasaran (Marketing)}

Strategi pemasaran berusaha menanamkan perusahaan dan produknya di benak pelanggan. Strategi ini bertujuan untuk mencapai how to win the market. Komponen dalam strategi pemasaran meliputi pemetaan pelanggan, kelompok pelanggan, aspek psikografis, dan lain sebagainya. Setelah diadakan pemisahan pelanggan (segmentasi), maka selanjutnya adalah menuju pasar sasaran (targeting). Apakah semua segmen pasar akan menjadi pasar yang dituju? Tentu saja jawabannya tergantung kepada kemampuan perusahaan.

Baitul Maal wat Tamwil (BMT) sebagai sekelompok orang yang menyatukan diri untuk saling membantu dan bekerja sama membangun sumber pelayanan keuangan guna mendorong dan mengembangkan usaha produktif dan peningkatan taraf hidup anggota keluarganya (Zakariah et al., 2017). Baitul Maal wat Tamwil merupakan lembaga ekonomi atau lembaga keuangan syariah nonperbankan yang sifatnya informal. Disebut bersifat informal karena lembaga keuangan ini didirikan oleh Kelompok Swadaya Masyarakat (KSM) yang berbeda dengan lembaga keuangan perbankan dan lembaga keuangan formal lainnya. BMT didirikan dan dikembangkan dengan suatu proses legalitas hukum yang bertahap. Awalnya dapat dimulai sebagai kelompok swadaya masyarakat dengan mendapatkan sertifikat operasi/kemitraan dari PINBUK dan jika telah mencapai nilai aset tertentu segera menyiapkan diri ke dalam badan hukum koperasi (Soemitra, 2009).

Berangkat dari kebijakan pengelolaan BMT yang memfokuskan anggotanya pada sektor keuangan dalam hal penghimpunan dana dan pendayagunaannya tersebut maka bentuk yang ideal BMT adalah koperasi simpan pinjam syariah yang selanjutnya pada tahun 2004 oleh Kementerian Koperasi disebut KJKS (Koperasi Jasa Keuangan Syariah). Berdasarkan keputusan Menteri Koperasi RI Nomor 91/Kep/M.KUKM/ IX/2004 tentang Petunjuk Pelaksanaan Kegiatan Usaha Koperasi Jasa Keuangan Syariah. Namun demikian, jika melihat dari banyaknya akadakad muamalah yang ada, tidak menutup kemungkinan Koperasi Syariah dapat berbentuk Koperasi Serba Usaha (KSU). Khususnya jika ditinjau dari akad jasa penyewaan, gadai, dan jual beli secara tunai (ba'i al-Musawamah). Sehingga dapat pula dikategorikan sebagai KSU Syariah.

\section{Penerapan Akad-akad yang relevan pada koperasi Syariah berbasis masjid}

Kegiatan koperasi syariah berbasis masjid ini tidak hanya mampu menumbuhkan konsep keuangan syariah, Juga mampu menghilangkan rentenir yang selama ini menjadi godaan sekaligus gangguan masyarakat. Akan tetapi Mengembangkan koperasi syariah berbasis masjid tidaklah mudah. Ketidakpahaman pengurus masjid di bidang ekonomi terkadang menjadi ganjalan. Pasalnya minimal ada 20 orang untuk membentuk koperasi syariah baru. Masalah modal juga menjadi kendala.

Masjid-masjid yang mendirikan Koperasi syariah, kebanyakan dari sisi pengelolaanya masih belum memahmi dan mengenal lebih jauh terkait akad akad syariah yang bisa digunakan. kebanyakan dari beberapa koperasi yang ada di masjid-mesjid masih terpaku dengan akad pinjaman saja, sehingga ketika dana itu disalurkan kepada masyarakat masjid, karena akad yang digunakan adalah pinjaman sehingga tidak boleh ada kelebihan, pengurus hanya menekankan pengembaliannya disertai dengan infak seikhlasanya, karena ditakutkan terjebak dengan riba.

Oleh karena itu yang Namanya koperasi adalah badan usaha yang artinya harus ada kegiatan ekonomi yang menghasilkan atau menguntungkan untuk kesejahteraan anggotanya. Maka kalau kita identifikasi lebih dalam terkait akad akad Syariah yang ada pada literatur fikih 


\section{Vol 3 No 3 (2022) 584-598 P-ISSN 2620-295 E-ISSN 2747-0490 DOI: 1047467/elmal.v3i3.941}

muamalah, maka ada beberapa akad yang relevan yang bisa diimplementasikan di koperasi Syariah berbasis masjid ini sehingga koperasi masjid bisa berkembang tidak hanya menggunakan akad pinjaman saja yang tentu kalau disyaratkan ada kelebihan maka termasuk riba. Maka langkah pertama sebelum mengimplementasikan akad-akad apa saja yang relevan untuk diterapkan di koperasi Syariah berbasis masjid ini, yang perlu dipastikan adalah menentukan jenis koperasi itu sendiri. Selain itu, koperasi dibagi menjadi koperasi primer atau sekunder. Pembentukan koperasi primer ini terdiri dari minimal 20 orang, sedangkan koperasi sekunder minimal 3 koperasi. Walaupun UU ini sudah dibatalkan berdasarkan keputusan Mahkamah Konstitusi dengan Undang-undang Nomor 17 Tahun 2012 Tentang Perkoperasian. Menyebutkan bahwa Jenis-jenis koperasi menurut UndangUndang tersebut sebagai berikut:

- Pertama. Koperasi konsumen, adalah koperasi yang menyelenggaarakan kegitan usaha pelayanan di bidang penyediaan barang kebutuhan anggota dan non anggota (pasal 84, ayat 1)

- Kedua. Koperasi Produsen adalah koperasi yang menyelenggarakan kegiatan usaha pelayanan di bidang pengadaan sarana produksi dan pemasaran produksi yang dihasilkan anggota kepada anggota dan non anggota (Pasal 84, ayat 2).

- Ketiga. Koperasi Jasa, adalah koperasi yang meyelenggarakan kegiatan usaha pelayanan jasa no simpan pinjam yang diperlukan oleh anggota dan non anggota (pasal 84, ayat 3).

- Keempat. Koperasi Simpan Pinjam, adalah koperasi yang menjalankan usaha simpan pinjam sebagai satu-satunya usaha yang melayani anggota (Pasal 84, ayat 4).

Dari pemaparan jenis koperasi di atas, maka tentu keempatnya bisa diterapkan pada koperasi Syariah berbasis masjid dengan berpatokan kepada kesamaan usaha para anggotanya dan yang sangat relevan untuk dipilih adalah koperasi simpang pinjam pada poin keempat tentu bukan hanya simpan pinjam, karena kalau hanya simpan pinjam maka pola yang akan dibangun adalah bunga yang tentu tidak sesuai dengan prinsip koperasi Syariah.

Peluang dan Tantangan Kemitraan Industri Keuangan Non Bank Syariah dan Lembaga Amil Zakat dalam Pengelolaan Dana ZISWAF. Peluang dan tantangan pengelolaan zakat oleh IKNBS dapat ditinjau dari aspek regulasi, kelembagaan, dan sumber daya manusia dan teknologi. Pada sisi regulasi, Peraturan Menteri Agama No 52 tahun 2014 telah menyiratkan kebolehan mendayagunakan dana zakat untuk usaha produktif dengan syarat sebagaimana pasal 33:

a) apabila kebutuhan dasar mustahik telah terpenuhi;

b) memenuhi ketentuan syariah;

c) menghasilkan nilai tambah ekonomi untuk mustahik;

d) mustahik berdomisili di wilayah kerja lembaga pengelola zakat.

Selanjutnya pada pasal 34 dinyatakan bahwa pendayagunaan zakat untuk usaha produktif dapat dilakukan paling sedikit memenuhi ketentuan: penerima manfaat merupakan perorangan atau kelompok yang memenuhi ketentuan mustahik; dan mendapat pemdampingan LAZ diwilayah domisili mustahik. Namun tantangan yang dihadapi terkait optimalisasi dana zakat yaitu belum adanya regulasi 'pemaksaan' zakat oleh negara, sebagaimana 'pemaksaan' pajak. Selanjutnya pada sisi kelembagaan, IKNBS memiliki berbagai jenis layanan yang sesuai dengan kebutuhan mustahik, misalnya asuransi syariah untuk layanan kesehatan dan pendidikan mustahik; pembiayaan syariah untuk pembiayaan produktif usaha mustahik; LKMS untuk bantuan modal mustahik dan sebagaimnya. Namun tantangan yang ada memang belum terdapatnya regulasi yang mengatur secara khusus pengelolaan zakat pada IKNBS. 


\section{Vol 3 No 3 (2022) 584-598 P-ISSN 2620-295 E-ISSN 2747-0490 DOI: 1047467/elmal.v3i3.941}

Islam adalah agama yang rahmatan lil alamiin bilamana ummat menjalankan ajarannya sesuai dengan Alquran dan sunnah insyaa Allah kemiskinan ummat islam Indonesia tidak akan terjadi seperti saat ini dimana angka kemiskinan mencapai 27,54 juta jiwa. Adapun kekuatan ummat islam dalam mengatasi kemiskinan dapat menggunakan kekuatan sosial berupa ZISWAT (Zakat, Infaq, Sadaqoh dan Wakaf) untuk digunakan dalam kegiatan produktif.

Hasil Penelitian terdahulu terkait dengan meningkatkan fungsi masjid tidak hanya sebagai kegiatan ibadah saja tetapi juga diberdayakan dalam kegiatan produktif dengan mendirikan Baitul Maal wal Tamwil dapat meningkatkan ekonomi ummat khususnya jamaah masjid sehingga akan berdampak terhadap kemandirian dalam mengatasi kemiskinan. Hasil penelitan terdahulu dalam meningkatkan fungsi masjid untuk pemberdayaan ekonomi ummat dengan mendirikan Baitul Maal wal Tamwil (BMT) dapat diklasifikasikan strategi yang digunakan oleh BMT dalam memberdayakan ekonomi ummat seperti pada tabel dibawah ini.

Tabel 2 : Artikel Berdasarkan Pembahasan

\begin{tabular}{|c|l|c|}
\hline 0 & \multicolumn{1}{|c|}{ TOPIK PEMBAHASAN } & JUMLAH \\
PAPER
\end{tabular}

\section{ZISWAF Sebagai Sumber Modal Dengan Biaya Murah}

Model Pemberdayaan ekonomi ummat berbasis masjid dengan menggunakan dana ZISWAF yang dikompulir dan dikelola oleh Baitul Maal wal Tamwil dalam penyalurannya kepada jamaah dilakukan dengan 2 tahapan sesuai dengan fungsi BMT sebagai lembaga sosial dan lembaga komersial untuk mendapatkan profit sebagai berikut: Sebagai Lembaga Sosial maka BMT sebelum menyalurkan bantuan dana untuk kegiatan ekonomi produktif dipastikan lebih dahulu bahwa penerimanya termasuk kedalam asnaf penerima zakat kategori miskin dan jamaah masjid, kemudian baru dilakukan pembinaan, pelatihan dan pendampingan supaya kedepannya jamaah tersebut dapat mandiri secara ekonomi dan hanya diwajibkan berinfaq seikhlas tanpa dikenakan untuk pengembalian dana bantuan.Selanjutnya, sebagai Lembaga Komersial maka BMT dalam menyalurkan pembiayaan kegiatan produktif kepada jamaah 


\section{Vol 3 No 3 (2022) 584-598 P-ISSN 2620-295 E-ISSN 2747-0490 DOI: 1047467/elmal.v3i3.941}

terlebih dahulu dilakukan akad atau kontrak kerja dengan konsep syariah yaitu bagi hasil untuk memberikan margin bagi kemajuan BMT.

\section{Sumber Daya Manusia}

Sistem pengembangan SDM yang dilakukan melalui tiga tahapan yaitu rekrutmen, pendidikan dan pelatihan, serta promosi jabatan. Rekrutmen dilaksanakan berdasarkan kebutuhan dari operasional BMT Masjid. Bentuk pelatihan yang diberikan kepada para petugas BMT berupa :

- Sistem Akuntansi Terintegrasi

- Fundamental Spiritual \& Motivation

- BIMTEK ADMINISTRA SI ORGANISASI KOPERASI

- Sertifikasi Kompetensi Manajer

- Pengelola Lembaga Keuangan Mikro Syariah

- Study Banding ke BMT yang sudah sukses melaksanakan pemberdayaan ekonomi ummat

Untuk terlaksana program pelatihan bagi petugas BMT dengan badan hukum koperasi syariah perlu dilakukan kerjasama dengan instansi terkait seperti : Dinas Koperasi yang menangani UKM (Usaha Kecil Mikro) dan Universitas berbasis Islam dengan Fakultas Ekonomi Bisnis Syariah

\section{Transfaransi dan Akuntanbilitas}

Untuk memberikan rasa aman dan kepercayaan kepada para anggota BMT Koperasi Syariah maupun para stakeholder yang sudah menanamkan dananya di BMT maka setiap transaksi akan dipertanggungjawabkan dalam laporan keuangan yang disajikan sesuai ketentuan dan standard laporan keuangan syariah yang mengacu pada ED PSAK 101 (2011:101.6) terdiri dari

a. laporan posisi keuangan,

b. laoran laba rugi,

c. laporan perubahan equitas,

d. laporan arus kas,

e. laporan sumber dan penyaluran dana zakat,

f. laporan sumber dan penggunaan dana kebajikan,

g. dan catatan atas laporan keuangan.

Penyajian laporan keuangan tersebut sesuai keputusan Menteri Negara Koperasi dan Usaha Kecil Dan Menengah Republik Indonesia Nomor: 91/Kep/M.KUKM/IX/2004 Tentang Petunjuk Pelaksanaan Kegiatan Usaha Koperasi Jasa Keuangan Syariah bahwa laporan perhitungan hasil usaha adalah laporan yang memberikan informasi tentang perhitungan penghasilan dan beban. Oleh karena itu pada Baitul Maal wa Tamwil (BMT) menyajikannya dalam sebutan Laporan Sisa Hasil Usaha (SHU).

\section{Tokoh Panutan}

Komunitas Masjid di Kampung Jogokariyan Yogyakarta yang dipimpin oleh para tokoh yang disegani maka komunitas masjid kampung yang dirintis sejak tahun 1960an ini telah mengalami perubahan sosial yang cukup signifikan yang menunjukkan bahwa faktor solidaritas kebangunan agama telah mendorong gerakan ekonomi-politik. Hal ini menjadi karakteristik yang kolektif pada gerakan Islam secara kontemporer pada perkotaan Jawa dimana masjid 


\section{Vol 3 No 3 (2022) 584-598 P-ISSN 2620-295 E-ISSN 2747-0490 DOI: 1047467/elmal.v3i3.941}

menjadi pusat dan basis gerakan Islam dengan infrastruktur ekonomi dan pendidikan politik yang tertata.

Penelitian ini fokus pada Strategi Baitul Maal wal Tamwil dalam mengoptimalkan Fungsi Masjid dengan Memberdayakan Ekonomi Jamaah Masjid, adapun artikel terkait dengan pembahasan tersebut adalah seperti tabel dibawah ini :

\begin{tabular}{|c|c|c|}
\hline No & Nama Penulis Artikel & Judul Artikel \\
\hline 1 & MF Abdillah & $\begin{array}{l}\text { Infak Masjid At Taufiq Pailus Untuk Pembiayaan } \\
\text { Menurut Maqasid Al-Syariah Jasser Auda }\end{array}$ \\
\hline 2 & Pauzi Muhammad & $\begin{array}{l}\text { Keadilan Dan Pemerataan Ekonomi Melalui Konsep } \\
\text { Baitul Mal Wat Tamwil (BMT) }\end{array}$ \\
\hline 3 & N Ngimadudin & Masjid Pusat Ekonomi Kerakyatan \\
\hline 4 & M Syarifudin & $\begin{array}{l}\text { Mencetak Muzakki Baru Melaluioptimalisasi Program } \\
\text { Komunitas Usaha Mikro Muamalat Berbasis Masjid }\end{array}$ \\
\hline 5 & $\begin{array}{l}\text { Muhammad } \\
\text { SE.Sy., MEI. }\end{array}$ & $\begin{array}{l}\text { Model Pemberdayaan Ekonomi Masyarakat Melalui } \\
\text { Pengelolaan Zakat, Infaq Dan Shadaqah (Zis) Di } \\
\text { Masjid Besar Syarif Hidayatullah Karangploso Malang }\end{array}$ \\
\hline 6 & $\begin{array}{l}\text { A Suryanto, A } \\
\text { Saepulloh }\end{array}$ & $\begin{array}{l}\text { Optimalisasi Fungsi Dan Potensi Masjid: Model } \\
\text { Pemberdayaan Ekonomi Masyarakat Berbasis Masjid } \\
\text { Di Kota Tasikmalaya }\end{array}$ \\
\hline 7 & $\begin{array}{l}\text { Muhammad Muhib } \\
\text { Alwi }\end{array}$ & $\begin{array}{l}\text { Optimalisasi Fungsi Masjid Dalam Pemberdayaan } \\
\text { Ekonomi Masyarakat }\end{array}$ \\
\hline 8 & $\begin{array}{l}\text { G Santika, IM Fauzi, W } \\
\text { Lisnawati }\end{array}$ & $\begin{array}{l}\text { Optimalisasi Potensi Masjid Sebagai Basis Penguatan } \\
\text { Ekonomi Mikro Syariah Di Bmt Mesjid Almuhsinin } \\
\text { Ciamis }\end{array}$ \\
\hline 9 & Muhammad Muhib Alw & $\begin{array}{l}\text { Pemberdayaan Ekonomi Masyarakat Berbasis Masjid } \\
\text { Di Tengah Pandemi Covid-19 }\end{array}$ \\
\hline 10 & F Melina & $\begin{array}{l}\text { Pembiayaan Murabahah di Baitul Maal wat Tamwil } \\
\text { (BMT) }\end{array}$ \\
\hline 11 & $\begin{array}{l}\text { N Annisa, N Naidah, I } \\
\text { Rasulong }\end{array}$ & $\begin{array}{l}\text { Peran Koperasi Simpan Pinjam Dana Niaga Syariah } \\
\text { Dalam Pemberdayaan Ekonomi Masyarakat Sebagai } \\
\text { Alternatif Untuk Mengurangi Tingkat Kemiskinan Di } \\
\text { Desa Lempangan Kecamatan Bajeng Kabupaten Gowa }\end{array}$ \\
\hline 12 & $\begin{array}{l}\text { MB Al-Banjary, } \\
\text { Dahliana }\end{array}$ & $\begin{array}{l}\text { Persepsi Nasabah Terhadap Peran BMT Kota } \\
\text { Banjarmasin }\end{array}$ \\
\hline 13 & Nur Fadhillah & Wakaf Produktif Dalam Meningkatkan Ekonomi Umat \\
\hline 14 & E Syarif & $\begin{array}{l}\text { Analisis Pengelolaan Dana Di Baitul Maal Wa Tamwil } \\
\text { An Nahl Tasikmalaya }\end{array}$ \\
\hline 15 & M Paramita & $\begin{array}{l}\text { Analisis Sistem Pengembangan Sumber Daya } \\
\text { Manusia Di Lembaga Keuangan Mikro Syariah }\end{array}$ \\
\hline
\end{tabular}


Vol 3 No 3 (2022) 584-598 P-ISSN 2620-295 E-ISSN 2747-0490 DOI: 1047467/elmal.v3i3.941

\begin{tabular}{|c|c|c|}
\hline 16 & Y Fadhilah, I Zaki & $\begin{array}{l}\text { Implementasi Peran Koperasi dalam Pemberdayaan } \\
\text { dan Kemandirian Pondok (Studi Kasus pada Pondok } \\
\text { Pesantren Mukmin Mandiri Sidoarjo) }\end{array}$ \\
\hline 17 & $\begin{array}{l}\text { Cc Cupian, W Wulanda, } \\
\text { R Rahadatul... }\end{array}$ & $\begin{array}{l}\text { Pengaruh Sinergi Organisasi Syamil Unpad Terhadap } \\
\text { Kemakmuran Masjid Raya Unpad Di Bulan Ramadhan } \\
\text { Tahun } 2019\end{array}$ \\
\hline 18 & $\begin{array}{l}\text { W } \quad \text { Munawar, } \mathrm{S} \\
\text { Qomaruddin }\end{array}$ & $\begin{array}{l}\text { Peningkatan Kapasitas Pengurus Dewan } \\
\text { Kemakmuran Masjid Assakinah Dalam } \\
\text { Pemberdayaan Ekonomi }\end{array}$ \\
\hline 19 & AA Muthalib & $\begin{array}{l}\text { Prospek pemberdayaan ekonomi masyarakat } \\
\text { berbasis masjid di kota watampone }\end{array}$ \\
\hline 20 & T Hendra, I Irsadunas & $\begin{array}{l}\text { Serapan Lembaga Keuangan Mikro Syariah Di } \\
\text { Sumatera Barat Terhadap Lulusan Program Studi D. } \\
\text { Iii Manajemen Perbankan Syariah }\end{array}$ \\
\hline 21 & $\begin{array}{l}\text { Jamaluddin Arsyad, } \\
\text { Zulqarnin, Arfan, Bujang } \\
\text { Dek, Mares Zulpiar }\end{array}$ & $\begin{array}{l}\text { Upaya Pemberdayaan Masjid sebagai Pusat Kegiatan } \\
\text { dan } \\
\text { Layanan Sosial Kecamatan Alam Barajo Provinsi } \\
\text { Jambi }\end{array}$ \\
\hline 22 & MA Zatalini, I Subaweh & $\begin{array}{l}\text { Analysis and design accounting information system } \\
\text { of funding and financing at Koperasi Serba Usaha } \\
\text { Syariah Baitul Maal Wat Tamwil Bakti Nurul Huda }\end{array}$ \\
\hline 23 & S Muchlis, R Auliah & $\begin{array}{l}\text { Implementasi Islamic Social Reporting dalam } \\
\text { Pengembangan Pembiayaan Koperasi Syariah BTM } \\
\text { Al-Kautsar }\end{array}$ \\
\hline 24 & R Wulandari & $\begin{array}{l}\text { Penerapan Standar Akuntansi Keuangan Syariah } \\
\text { Dalam Penyajian Laporan Keuangan Baitul Maal Wa } \\
\text { Tamwil Di Pontianak }\end{array}$ \\
\hline 25 & $\begin{array}{l}\text { Yulia Hamdaini Putri1 } \\
\text { Ahmad Syathiri2 }\end{array}$ & $\begin{array}{l}\text { Pengaruh Persepsi Dan Minat Terhadap Keberadaan } \\
\text { Baitul Mal Wattamwil (Bmt) Di Kota Palembang }\end{array}$ \\
\hline 26 & E Erman & $\begin{array}{l}\text { Standar Kompetensi Pengelola Koperasi Simpan } \\
\text { Pinjam Syariah Di Bmt Taqwa Muhammadiyah } \\
\text { Padang }\end{array}$ \\
\hline 27 & H Khatimah & $\begin{array}{l}\text { Analisis Efektivitas Inklusi Keuangan Di BMT Syariah } \\
\text { Riyal }\end{array}$ \\
\hline 28 & Nur Eka Setiowati & $\begin{array}{l}\text { Baitul Mal Wat Tamwil Sebagai Aplikasi Program } \\
\text { Financial Inclusion Dalam Peningkatan Akses Bagi } \\
\text { Kesejahteraan Masyarakat Kecil Dan Menengah }\end{array}$ \\
\hline 29 & RS Dewi & $\begin{array}{l}\text { Pemberdayaan Masjid di Indonesia dalam Perspektif } \\
\text { Institutional Building }\end{array}$ \\
\hline 30 & H Hasmayati & $\begin{array}{l}\text { Analisis Penilaian Kesehatan Koperasi Jasa Keuangan } \\
\text { Syariah Berbasis Masjid (Studi Kasus Koperasi Jasa }\end{array}$ \\
\hline
\end{tabular}


Vol 3 No 3 (2022) 584-598 P-ISSN 2620-295 E-ISSN 2747-0490 DOI: 1047467/elmal.v3i3.941

\begin{tabular}{|c|c|c|}
\hline & & $\begin{array}{l}\text { Keuangan Syariahbaitul Mal Tamwil At-taqwa-masjid } \\
\text { At-taqwa Kemanggisan Jakarta) }\end{array}$ \\
\hline 31 & J Jalaluddin, R Audia & $\begin{array}{l}\text { Faktor-Faktor Yang Memengaruhi Keputusan } \\
\text { Masyarakat Menjadi Anggota Koperasi Syariah } 212 \\
\text { (Studi Kasus Di Banda Aceh Dan Aceh Besar }\end{array}$ \\
\hline 32 & M Subhan & $\begin{array}{l}\text { Strategi Pemasaran Syari'ah Pada BMT Al-Amanah } \\
\text { Dalam Meningkatkan Modal Dan Penyaluran } \\
\text { Pembiayaan }\end{array}$ \\
\hline 33 & AR Anshori & $\begin{array}{l}\text { Analisis Penerapan Akad-Akad Syariah Yang Relevan } \\
\text { Pada Koperasi Syariah Berbasis Masjid Sebagai } \\
\text { Upaya Pemberdayaan Ekonomi Masyarakat Masjid }\end{array}$ \\
\hline 34 & I Junita & $\begin{array}{l}\text { Pengaruh Muqashsha Dalam Piutang Murabahah } \\
\text { Terhadap Pendapatan Baitul Qiradh Bina Insan } \\
\text { Mandiri Banda Aceh }\end{array}$ \\
\hline 35 & S Kurniadi & $\begin{array}{l}\text { Pengaruh Pembiayaan Murabahah, Terhadap Laba } \\
\text { Koperasi Surya Lestari Syariah Kabupaten Bungo }\end{array}$ \\
\hline 36 & $\begin{array}{l}\text { I Sutiawan, } \quad \text { M } \\
\text { Mulyaningsih }\end{array}$ & $\begin{array}{l}\text { Analisis Pelaksanaan Kebijakan Pembinaan Usaha } \\
\text { Mikro Kecil dan Menengah Terhadap Kinerja Bisnis } \\
\text { Dalam Mewujudkan Efektivitas Kelangsungan Usaha } \\
\text { di Kabupaten Garut }\end{array}$ \\
\hline 37 & HSR Funna, S Suazhari & $\begin{array}{l}\text { Analisis Pengukuran Kinerja Koperasi Syariah } \\
\text { Berdasarkan Balanced Scorecard (Studi Pada } \\
\text { Koperasi Syariah Baiturrahman Banda Aceh) }\end{array}$ \\
\hline 38 & RM Ag & $\begin{array}{l}\text { Pemaksimalan Fungsi Mesjid sebagai Basis Ekonomi } \\
\text { Jamaah di Mesjid Raya Salimpaung }\end{array}$ \\
\hline 39 & N Nashirun & $\begin{array}{l}\text { Pendampingan Pendirian Bmt Di Kecamatan } \\
\text { Tekarang }\end{array}$ \\
\hline 40 & E Ernawati & $\begin{array}{l}\text { Jaringan Pengelolaan Zakat untuk Pertumbuhan } \\
\text { Industri Keuangan Non Bank Syariah }\end{array}$ \\
\hline 41 & AM Arrozy & $\begin{array}{l}\text { Perubahan Sosial Komunitas Masjid Kampung } \\
\text { Jogokariyan Yogyakarta Tinjauan Sosiologi-Sejarah }\end{array}$ \\
\hline
\end{tabular}

\section{KESIMPULAN}

Hasil dari kajian Studi Literatur dari 41 artikel yang terpilih menunjukan bahwa Pendirian Baitul Maal wal Tamwil berbasis masjid dapat meningkatkan kegiatan ekonomi ummat yang akan berdampak terhadap kemandirian ekonomi ummat untuk mengatasi kemiskinan. Namun saat ini masih sedikit sekali masjid yang mempunyai badan usaha sosial dan bisnis seperti BMT dengan berbadan hukum koperasi syariah, bilamana jumlah masjid di Indonesia yang diperkirakan jumlahnya 800.000 masjid dapat saja memberdayakan ekonomi jamaahnya 50 jiwa per masjid tentu sudah dapat menurunkan angka kemiskinan 40 juta jiwa jauh dari angka kemiskinan yang dilaporkan oleh BPS, tentu hal ini memperlihatkan kepada kita 


\section{Vol 3 No 3 (2022) 584-598 P-ISSN 2620-295 E-ISSN 2747-0490 DOI: 1047467/elmal.v3i3.941}

bahwa meningkatkan fungsi masjid dalam kegiatan produktif dengan pendirian BMT akan dapat mengatasi kemiskinan di Indonesia yang mayoritas ummatnya beragama islam.

Penulis mengusulkan untuk penelitian selanjut dalam meningkatkan fungsi masjid dengan pendirian BMT di fokuskan pada Integrasi Badan Pengelolaan ZISWAF dengan BMT sehingga dengan terintegrasinya Kekuatan Sosial Ummat islam dalam pengelolaan ZISWAF dengan kegiatan bisnis masjid tentu resiko bisnis dan operasional BMT yang dihadapi dapat disolusikan untuk kesinambungan keberadaan BMT di masjid.

\section{DAFTAR PUSTAKA}

Alwi, M.A., M. M. (2020). Pemberdayaan Ekonomi Masyarakat Berbasis Masjid di Tengah Pandemi Covid-19. Jurnal Al-Hikmah, 18(1), 99-116. https://doi.org/10.35719/alhikmah.v18i1.25

Fadhilah, Y., \& Zaki, I. (2019). Implementasi Peran Koperasi dalam Pemberdayaan dan Kemandirian Pondok (Studi Kasus pada Pondok Pesantren Mukmin Mandiri Sidoarjo). In Jurnal Ekonomi Syariah Teori dan Terapan. scholar.archive.org.

Hendratmi, A., \& Widayanti, M. A. (2017). Business Model in Islamic Perspective: Practising of Baitul Maal Wattamwil (BMT) UGT Sidogiri East Java Indonesia. GATR Journal of Management and Marketing Review, 2(1), 43-52. https://doi.org/10.35609/jmmr.2017.2.1(7)

Khatimah, H. (2016). Analisis Efektivitas Inklusi Keuangan Di BMT Syariah Riyal. ... : Jurnal Ekonomi Dan Kewirausahaan.

Maulana, M. I., \& Akbar, N. (2019). a Potential of Baitul Mal Wa Tamwil (Bmt) in Developing the Border Area of Indonesia - Malaysia. Al-Iqtishad: Jurnal Ilmu Ekonomi Syariah, 11(1), 97116. https://doi.org/10.15408/aiq.v11i1.6834

Muhammad Akhyar Adnan Shochrul Rohmatul Ajija. (2015). The effectiveness of Baitul Maal wat Tamwil in reducing poverty". Humanomics, 31, 104. https://doi.org/http://dx.doi.org/10.1108/H-03-2012-0003

Muthalib, A. A. (2018). Prospek pemberdayaan ekonomi masyarakat berbasis masjid di kota watampone. Jurnal Iqtisaduna.

Quraisy, M., Hamzah, S., \& Razak, A. (2017). the Impact of Islamic Microfinance in Enhancing the Well-Being and Quality of Life : Case Study of Islamic Financial Cooperative ( Bmt) in Indonesia. South East Asia Journal of Contemporary Business, Economics and Law, 13(3), 112. file:///C:/Users/HP/Downloads/IMF Week 2.pdf

Wibowo, K. A. (2020). Transformation of Islamic Financial Literacy in the Member of BMT in Indonesia Through Community Development MKU Methods. SSRN Electronic Journal, 1-5. 
Vol 3 No 3 (2022) 584-598 P-ISSN 2620-295 E-ISSN 2747-0490 DOI: 1047467/elmal.v3i3.941

https://doi.org/10.2139/ssrn.3678336

Wulandari, P. (2019). Enhancing the role of Baitul Maal in giving Qardhul Hassan financing to the poor at the bottom of the economic pyramid: Case study of Baitul Maal wa Tamwil in Indonesia. Journal of Islamic Accounting and Business Research, 10(3), 382-391. https://doi.org/10.1108/JIABR-01-2017-0005

Wulandari, P., \& Kassim, S. (2016). Issues and challenges in financing the poor: case of Baitul Maal Wa Tamwil in Indonesia. International Journal of Bank Marketing, 34(2), 216-234. https://doi.org/10.1108/IJBM-01-2015-0007

Zakariah, M., Zakariah, M., Astuti, D., \& Maryam, S. (2017). Analysis Factor of Marketing Strategy of Funding Decision of Customers Choose Baitul Mal Wat Tamwil (BMT) In Kolaka Regency, Indonesia. Jurnal Ekonomi Bisnis Islam, 1, 38-47. https://doi.org/10.5281/zenodo.1148845

Zatalini, M. A., \& Subaweh, I. (2019). Analysis and design accounting information system of funding and financing at Koperasi Serba Usaha Syariah Baitul Maal Wat Tamwil Bakti Nurul Huda. Jurnal Ilmiah Ekonomi Bisnis. 